\title{
Expanding Due Diligence: Human Rights Risk Assessments and Limits to State Interventions Aimed at Preventing Domestic Violence
}

Leyla-Denisa Obreja*

https://doi.org/10.21827/GroJIL.7.2.182-194

\section{Keywords \\ HUMAN RIGHTS; DOMESTIC VIOLENCE; DUE DILIGENCE; RISK ASSESSMENT; INTIMATE PARTNER VIOLENCE}

\begin{abstract}
Much has been discussed about the consolidating due diligence doctrine in the field of international human rights law and how it applies to intimate partner violence (IPV) and other forms of violence against women (VAW). Due diligence obligations to prevent IPV contain programmatic elements, guiding States to intervene and prevent human rights violations arising from IPV. This article demonstrates that in the case of IPV, human rights violations can be primary and secondary. The article then discusses due diligence in the context of IPV prevention, revealing two important State conducts: anticipative prevention and escalation mitigation. The article explains that States' due diligence obligations to prevent IPV contain obligations to address both primary and secondary human rights violations and introduce developments to the current prevention model. The article proposes that to prevent IPV and other forms of VAW, States should perform human rights risk assessments. However, deriving State interventions can be often limited by the right to private and family life, making it necessary to incorporate the victim's agency, needs and wishes within the risk-assessment process as well as following intervention.
\end{abstract}

\section{Introduction}

In international human rights law, due diligence appears in Velasquez Rodriguez v Honduras, where the Inter-American Court of Human Rights states that 'An illegal act which violates human rights [...] can lead to international responsibility of the State not because of the act itself but because of the lack of due diligence to prevent the violation."

Due diligence reflects an ongoing development of the responsibility of States for private acts and omissions, as opposed to the classical conditioning of international law, establishing liability only for the public acts of States. ${ }^{2}$ Due diligence implies that when States fail to intervene and prevent human rights violations between private actors, they are liable for negligence. However, due diligence obligations have only embraced certain

* Bond University, Queensland, Australia, Faculty of Law. This research was supported by an Australian Government Research Training Program Scholarship. Email: lobreja@bond.edu.au; obreja.leyla@gmail.com.

1 Velasquez Rodriguez v Honduras, Judgement, Inter-American Court of Human Rights Series C No 4 (29 July 1988) [172].

2 ILA Study Group on Due Diligence in International Law, 'First Report' (ILA Study Group, 7 March 2014) <olympereseauinternational.files.wordpress.com/2015/07/due_diligence__first_report_2014.pdf> accessed 10 November 2019; ILA Study Group on Due Diligence in International Law, 'Second Report' (ILA Study Group, July 2016). 


\section{Expanding Due Diligence: Human Rights Risk Assessments and Limits to State Interventions Aimed at Preventing Domestic Violence 183}

thematic areas, among which is gender-based violence. ${ }^{3}$ The most recent document regulating due diligence is the Istanbul Convention on Preventing and Combating Violence against Women and Domestic Violence, wherein it is stated that

Parties shall take the necessary legislative and other measures to exercise due diligence to prevent, investigate, punish and provide reparation for acts of violence covered by the scope of this Convention that are perpetrated by non-State actors. ${ }^{4}$

From the point of view of international human rights law, IPV can represent a violation of the following rights:

- $\quad$ the right to life
-
-
-
-
right to equalition of to sexual and reproductive health ${ }^{8}$
right to housing

3 UN Committee for the Elimination of All Forms of Discrimination against Women (UNCEDAW), 'General Recommendation No 19: Violence Against Women' in 'Note by the Secretariat, Compilation of General Comments and General Recommendations Adopted by Human Rights Treaty Bodies' (29 July 1994) UN Doc HRI/GEN/1/Rev.1; UN Committee for the Elimination of Discrimination Against Women, 'General Recommendation No 35 on Gender-based Violence Against Women, Updating General Recommendation No 19' (14 July 2017) UN Doc CEDAW/C/GC/35 para 34.

4 Council of Europe Convention on Preventing and Combating Violence against Women and Domestic Violence (CETS No 210).

5 United Nations International Covenant on Civil and Political Rights (ICCPR) (adopted 16 December 1966, entered into force 23 March 1976) 999 UNTS 171 art 6; UN Human Rights Committee 'General Comment 6' in 'Note by the Secretariat, Compilation of General Comments and General Recommendations adopted by Human Rights Treaty Bodies' (1994) UN Doc HRI/GEN/1/Rev.1 para 5; UN Human Rights Committee 'Draft General Comment 36 of the United Nations Human Rights Committee' (14 July 2015) UN Doc CCPR/C/GC/R36/Rev2.

6 UN Convention Against Torture and Other Cruel, Inhuman or Degrading Treatment or Punishment (adopted 10 December 1984, entered into force 26 June 1987) 1465 UNTS 85 art 1; United Nations Committee Against Torture (UNCAT) 'General Comment No 2: Implementation of Article 2 by States Parties' (24 January 2008) UN Doc CAT/C/GC/2 para. 18 'Where State authorities or others acting in official capacity or under color of law, know or have reasonable grounds to believe that acts of torture or ill-treatment are being committed by non-State officials or private actors and they fail to exercise due diligence to prevent, investigate, prosecute and punish such non-State officials or private actors consistently with the Convention, the State bears responsibility and its officials should be considered as authors, complicit or otherwise responsible under the Convention for consenting to or acquiescing in such impermissible acts.'; Rhonda Copelon, 'Recognizing the Egregious in the Everyday: Domestic Violence as Torture' (1993-1994) 25(2) Columbia Human Rights Law Review 291, 296.

7 UN Convention on the Elimination of All Forms of Discrimination Against Women (CEDAW) (adopted 18 December 1979, entered into force 3 September 1981) 1249 UNTS 13; UNCEDAW (n 3).

8 UN Committee on Economic, Social and Cultural Rights 'General Comment No 22 on the Right to Sexual and Reproductive Health (Article 12 of the International Covenant on Economic, Social and Cultural Rights)' (2 May 2016) UN Doc E/C.12/GC/22; ICCPR (n 5) art 12; Shane M Trawick, 'Birth Control Sabotage as Domestic Violence: A Legal Response' (2012) 100 California Law Review 721, 733; C Shalev, 'Rights to Sexual and Reproductive Health: the ICPD and the Convention on the Elimination of All Forms of Discrimination Against Women' (International Conference on Reproductive Health, Mumbai, 15-19 March 1998).

9 UN Committee on Economic, Social and Cultural Rights 'General Comment No 7: The Right to Adequate Housing: Forced Evictions' (20 May 1997) UN Doc E/C.12/1997/4 para. 3; UN Office of the High Commissioner for Human Rights, Women and the Right to Adequate Housing (United Nations 
- $\quad$ the right of people with disabilities to freedom from violence ${ }^{10}$

- the right to a fair trial and access to justice. ${ }^{11}$

The obligations of States to prevent human rights violations associated with IPV and VAW have been thoroughly examined in the literature. ${ }^{12}$ Due diligence obligations to prevent IPV and other forms of VAW have also had significant recognition in international litigation and have been reinforced by a number of decisions of regional and international human rights bodies. These include, in the Inter-American system, the case of Maria da Penha Maia Fernandes $v$ Brazil, ${ }^{13}$ the case of Jessica Lenahan $v$ United States ${ }^{14}$ and the aforementioned Velasquez Rodriguez $v$ Honduras. ${ }^{15}$ The United Nations Committee on the Elimination of Discrimination Against Women (CEDAW Committee) has also upheld the due diligence standard in the case of AT v Hungary, ${ }^{16}$ Yildirim v Austria, ${ }^{17}$ Angela González Carreño $v$ Spain $^{18}$ and $X$ and $Y v$ Georgia. ${ }^{19}$ The European Court of Human Rights (ECtHR) also had a significant impact on the development of due diligence obligations, stemming

Publications 2012) 76; Helene Combrinck, 'Living in Security, Peace and Dignity: The Right to Have Access to Housing of Women Who Are Victims of Gender-based Violence' (Research Series 5, SocioEconomic Rights Project, University of the Western Cape Community Law Centre 2009).

10 UN Convention on the Rights of Persons with Disabilities (adopted 13 December 2006, entered into force 3 May 2008) 2515 UNTS 3; Keran Howe, 'Violence Against Women with Disabilities - An Overview of the Literature' (1999) 7 Australian Feminist Journal 11; Dena Hassouneh-Phillips and Mary Ann Curry, 'Abuse of Women with Disabilities: State of the Science' (2002) 45(2) Rehabilitation Counseling Bulletin 96; Michelle McCarthy, "What Kind of Abuse is Him Spitting in My Food?": Reflections on the Similarities Between Disability Hate Crime, So-called "Mate" Crime and Domestic Violence Against Women with Intellectual Disabilities' (2017) 32(4) Disability \& Society 595, 599.

11 UN Human Rights Committee, 'General Comment 32, Article 14: Right to Equality Before Courts and Tribunals and to a Fair Trial' (23 August 2007) UN Doc CCPR/C/GC/32; International Commission of Jurists, Women's Access to Justice for Gender-Based Violence: Practitioners Guide (International Commission of Jurists 2016); see ICCPR (n 5) articles 2(1), 3, 14, 26; CEDAW (n 7) arts 2, 15; Convention for the Protection of Human Rights and Fundamental Freedoms (European Convention on Human Rights, as amended) (ECHR) arts 6(1), 14; Protocol 12 to the European Convention on Human Rights art 1; African Charter on Human and Peoples' Rights (adopted 27 June 1981, entered into force 21 October 1986) (1982) 21 ILM 58 (African Charter) arts 2, 3, 6, 7, 8, 26; Protocol to the African Charter on Human and Peoples' Rights (Maputo Protocol) art 8.

12 Zarizana Abdul Aziz and Janine Moussa, 'Due Diligence Framework: State Accountability Framework for Eliminating Violence against Women' (Due Diligence Project, 2014) <duediligenceproject.org> accessed 10 November 2019; Paulina García-Del Moral and Megan Alexandra Dersnah, 'A Feminist Challenge to the Gendered Politics of the Public/Private Divide: On Due Diligence, Domestic Violence and Citizenship' (2014) 18(6-7) Citizenship Studies 661; Jeremy Sarkin, 'A Methodology to Ensure that States Adequately Apply Due Diligence Standards and Processes to Significantly Impact Levels of Violence Against Women Around the World' (2018) 40(1) Human Rights Quarterly 1.

13 Maria da Penha Maia Fernandes v Brazil Case 12.051 (Admissibility) Inter-American Court of Human Rights Report No 54/01 (16 April 2001).

14 Lenahan (Gonzales) et al. v United States Case 12.626 (Merits) Inter-American Court of Human Rights Report No 80/11 (21 July 2011) paras 20-30.

15 Velasquez Rodriguez v Honduras (n 1).

16 AT v Hungary (26 January 2005) UN CEDAW Communication No 2/2003 UN Doc CEDAW/C/32/D/2/2003.

17 Yildirim $v$ Austria (6 August 2007) UN CEDAW Communication No 6/2005 UN Doc CEDAW/C/39/D/6/2005.

18 González Carreño v Spain (16 July 2014) UN CEDAW Communication No 46/2012 UN Doc CEDAW/C/58/D/47/2012.

$19 X$ and $Y v$ Georgia (25 August 2015) UN CEDAW Communication No 24/2009 UN Doc CEDAW/C/61/D/24/2009. 
from the cases of Opuz v Turkey, ${ }^{20}$ Kontrovà $v$ Slovakia, ${ }^{21}$ Balsan $v$ Romania, ${ }^{22}$ Valiulienè $v$ Lithuania $^{23}$ and $A v$ Croatia, ${ }^{24}$ among many others.

The main approach to the analysis of due diligence was to design frameworks known as the $5 \mathrm{Ps}$ or $7 \mathrm{Ps} .{ }^{25}$ These frameworks illustrate normative and policy guidelines to protect victims, prosecute gender-based violence, provide redress for human rights violations and generally prevent violence against women. ${ }^{26}$ They deliver valuable guiding principles for public stakeholders in IPV. However, the current model of due diligence obligations to prevent IPV fails to pay adequate attention to the granularity of risk factors in IPV and the centrality of human rights risks in the design of State interventions. This article makes various contributions to the due diligence standard for preventing IPV. First, it underlines the relationship between risk factors for IPV and human rights, using a socioecological approach to IPV. Then, it illustrates how a risk-based approach to IPV requires anticipative prevention and escalation mitigation to prevent primary and secondary human rights violations in IPV. Finally, it analyses limitations to due diligence obligations, with a special focus on victim agency and the victim's right to private and family life. These developments are aimed at clarifying the adequate State conduct required to comply with human rights obligations to prevent and combat IPV and, implicitly, VAW. This article also demonstrates the importance of integrating human rights into the risk-assessment tools already utilised by State actors.

\section{IPV as a Risk-based Phenomenon with Human Rights Implications 2.1 IPV and the Problem of Causation}

IPV is any 'behaviour by an intimate partner (current and former) that causes physical, sexual or psychological harm, including acts of physical aggression, sexual coercion, psychological abuse and controlling behaviours. ${ }^{27}$ As a form of VAW, IPV has become increasingly publicised as authors in different scientific fields explored numerous accounts of IPV, ranging from socio-cultural accounts of violence against women and inter-personal accounts of family violence, to intra-personal interpretations of risk factors associated with violent behaviours. ${ }^{28}$ The scholarship struggles to deliver a definitive answer regarding the causes of IPV which, in turn, influences laws and policies aimed at combating IPV. There

20 Opuz v Turkey App no 33401/02 (ECHR, 9 June 2009).

21 Kontrova v Slovakia App no 7510/04 (ECHR, 31 May 2007).

22 Balsan v Romania App no 49645/09 (EHCR, 23 August 2017).

23 Valiulienè v Lithuania App no 33234/07 (EHCR, 26 June 2013).

24 Av Croatia App no 5164/08 (ECHR, 14 January 2011).

25 Aziz and Moussa (n 12); Sarkin (n 12).

26 Prevent, Protect, Prosecute, Punish and Provision of Redress are known as the 5Ps, see Aziz and Moussa (n 12).

27 World Health Organisation (WHO), 'Responding to Intimate Partner Violence and Sexual Violence Against Women: WHO Clinical and Policy Guidelines' (WHO 2013).

28 Erica Woodin and Daniel K O'Leary, 'Theoretical Approaches to the Etiology of Partner Violence' in DJ Whitaker and JR Lutzker (eds), Preventing Partner Violence: Research and Evidence-based Intervention Strategies (American Psychological Association 2009) 41; Kathryn M Bell and Amy E Naugle, 'Intimate Partner Violence Theoretical Considerations: Moving Towards a Contextual Framework' (2008) 28(7) Clinical Psychology Review 1096; Sandra M Stith et al, 'Intimate Partner Physical Abuse Perpetration and Victimization Risk Factors: A Meta-analytic Review' (2004) 10(1) Aggression and Violent Behaviour 65; Louise Dixon and Nicola Graham-Kevan, 'Understanding the Nature and Etiology of Intimate Partner Violence and Implications for Practice and Policy’ (2011) 31(7) Clinical Psychology Review 1145. 
is no one-size-fits-all State response guaranteed to eradicate IPV; a limitation attributed, among other aspects, to the fact that motivation is a disputed element of IPV:

Motivations are internal experiences that may be difficult for even the perpetrator to discern. Even when a perpetrator is able to accurately introspect about and subsequently identify their relevant motives, social desirability concerns may preclude admission of these motives. ${ }^{29}$

Moreover, IPV is a variable concept that fluctuates in different cultural settings and 'cultural justifications for violence usually follow from traditional notions of the proper roles of men and women. ${ }^{30}$ The way IPV and other forms of VAW are conceptualised is important because for States to prevent these phenomena, they must naturally understand how they arise, what defines perpetration and victimisation predispositions and how these tendencies can be combated through State interventions.

Feminists place patriarchy and gender roles at the centre of partner violence. Most feminist accounts adopt the position that men, supported by a historical and institutional dominance over women, have transferred that submissive quest into their relationships and that violence is a tool for maintaining power both in the public and private spheres. ${ }^{31}$ This approach also influenced international human rights law: from the Nairobi World Conference to the most recent interpretations of the CEDAW Committee, international human rights law has strongly linked VAW to the elements of inequality, gender and patriarchy. ${ }^{32}$

However, as early as 1994, Dutton observed that 'patriarchy must interact with psychological variables in order to account for the great variation in power-violence data. ${ }^{33}$ Since then, a growing number of authors have agreed that IPV is complex and must be viewed holistically, maintaining that gender and patriarchal attitudes are deterministic factors but do not exclusively explain the occurrence of IPV. ${ }^{34}$ In the past decade, the World Health Organisation (WHO) has adopted an ecological approach to IPV, maintaining that multiple elements such as gender, personality, stereotypes or socio-

29 Jennifer Langhinrichsen-Rohling, Adrianne McCullars and Tiffany Misra, 'Motivations for Men and Women's Intimate Partner Violence Perpetration: A Comprehensive Review' (2012) 3(4) Partner Abuse 429.

30 WHO, 'World Report on Violence and Health' (WHO 2002) <who.int/violence_injury_prevention/violence/world_report/en/introduction.pdf> accessed 10 November $2019 \mathrm{Ch}$ IV.

31 R Emerson Dobash and Russel Dobash, Violence Against Wives (Free Press 1979); Michelle Bograd, 'Feminist Perspectives on Wife Abuse: An Introduction' in Kersti Yllö and Michelle Bograd (eds), Feminist Perspectives on Wife Abuse (Sage 1988); Claire Houston, 'How Feminist Theory Became (Criminal) Law: Tracing the Path to Mandatory Criminal Intervention in Domestic Violence Cases' (2014) 21(1) Michigan Journal of Gender \& Law 217.

32 UNCEDAW (n 3); United Nations Division for the Advancement of Women, 'United Nations Information Note: The United Nations Work on Violence Against Women' (Nairobi World Conference, 15-26 July 1985); the Committee considers that gender-based violence against women is one of the fundamental social, political and economic means by which the subordinate position of women with respect to men and their stereotyped roles are perpetuated.

33 Donald Dutton, 'Patriarchy and Wife Assault: The Ecological Fallacy' (1994) 9(2) Violence and Victims 82, 167.

34 Lori Heise, 'What Works to Prevent Partner Violence? An Evidence Overview' (2011) Working Paper for the Policy Division of the UK Department for International Development, Version 2 <oecd.org/derec/49872444.pdf> accessed 10 November 2019; Parveen Azam Ali and Paul B Naylor, 'Intimate Partner Violence: A Narrative Review of the Feminist, Social and Ecological Explanations for its Causation' (2013) 18(6) Aggression and Violent Behaviour 611. 


\section{Expanding Due Diligence: Human Rights Risk Assessments and Limits to State Interventions Aimed at Preventing Domestic Violence 187}

economic factors influence IPV.$^{35}$ A multi-dynamic risk-based approach to IPV and other forms of VAW could maximise the impact of State interventions to prevent human rights violations associated with the phenomena.

\subsection{The Relationship Between Risk Factors and Human Rights}

If States internalise the assumption that IPV or other forms of VAW are caused by a single factor or one single category of risk factors, preventative approaches run the risk of placing the narrative of an individual in backlog, disregarding an individual's agency, rights, needs or personal circumstances. ${ }^{36}$ Considering IPV as a matter of mere gender discrimination leaves out the conditions that led an established vulnerability to be subjected to abuse, such as a lack of education, a socio-economic predisposition or mental health issues that only magnify in the presence of abuse.

As such, a constellation of human rights can be violated by private actors in interpersonal relationships if States fail to intervene or take all appropriate measures to combat violent societal climates. IPV or VAW are not just problems of equality but can represent violations of multiple human rights. It is clear that a holistic prevention model must consider all the possible risks that might influence IPV. An integrative explanation for IPV is the socio-ecological approach that allows for the transformation of gender dynamics at an individual, relational, community and societal levels. ${ }^{37}$ The dynamic nature of this approach allows for the consideration of new and evolving factors that might influence a phenomenon. ${ }^{38}$

The WHO has identified various individual risk factors for IPV perpetration by men, for example: young age; heavy drinking; depression; personality disorders; low academic achievement; low income and witnessing or experiencing violence as a child. ${ }^{39}$ Ten years later, the WHO includes factors for the victimisation of women: low levels of education; exposure to violence between parents; sexual abuse during childhood; acceptance of violence and exposure to other forms of prior abuse. ${ }^{40}$

Additional to individual risk factors, a person can experience exposure to a second category that will increase their chance of becoming a victim and perpetrator of IPV. The WHO mentions the following relational risk factors: marital conflict; marital instability; male dominance in the family; economic stress and poor family functioning, expanding the list in 2012 to include men having multiple partners and a disparity in educational attainment as relational risk factors. ${ }^{41}$

35 WHO (n 30); WHO, 'Understanding and Addressing Violence Against Women; Intimate Partner Violence' (WHO 2012) <apps.who.int/iris/bitstream/10665/77432/1/WHO_RHR_12.36_eng.pdf> accessed 19 December 2019.

36 Heise (n 34); Rachel Jewkes, Jonathan Levin and Loveday Penn-Kekana, 'Risk Factors for Domestic Violence: Findings from a South African Cross-sectional Study' (2002) 55(9) Social Science \& Medicine 1603; Lori Michau et al, 'Prevention of Violence Against Women and Girls: Lessons from Practice' (2015) 385(9978) The Lancet 1672; Miranda Sue Terry, 'Applying the Social Ecological Model to Violence against Women with Disabilities' (2014) 3(6) Journal of Women's Health Care.

37 Heise (n 34); Jewkes, Levin and Penn-Kekana (n 36); Michau et al (n 36); Terry (n 36); Tanya Abramsky et al, 'Ecological Pathways to Prevention: How does the SASA! Community Mobilisation Model Work to Prevent Physical Intimate Partner Violence Against Women?' (2016) 16(1) BMC Public Health 339.

38 Emma Fulu and Stephanie Miedema, 'Violence Against Women: Globalizing the Integrated Ecological Model' (2015) 21(2) Violence Against Women 1431; globalization should be a factor integrated into how VAW is theorised.

39 WHO (n 30).

40 WHO (n 35).

41 WHO (n 30); WHO (n 35). 
The third layer of risk factors for IPV is represented by cultural and societal contexts and climates, equivalent to the social-ecology levels of exosystem and microsystem. ${ }^{42}$ Social and cultural norms can be internalised by individuals in their pursuit of fitting in within their societies although at times they might conflict with their personal beliefs. ${ }^{43}$ Globally, social and cultural factors are: weak community sanctions against domestic violence; poverty; low social capital; traditional gender norms and social norms supportive of violence. ${ }^{44}$ Examples of social norms supportive of IPV are the belief that divorce is shameful, that a man has the right to exercise discipline over a woman and that a man is socially superior. ${ }^{45}$

An important observation surfaces if we bridge an ecological approach to IPV with the due diligence obligations of States to prevent IPV. What appear to be risk factors for IPV might, in fact, be unfulfilled human rights. The very occurrence of IPV might stem from primary human rights violations. For example, exposure to domestic violence in childhood can be viewed as violations of the right of the child. ${ }^{46}$ Risk factors such as heavy drinking, personality disorders and depression can be considered under the right to health, including the dimension of mental health, put forward in Article 12 of the International Covenant on Economic, Social and Cultural Rights. States have international obligations 'to take appropriate steps towards the full realization of everyone's right to the enjoyment of the highest attainable standard of physical and mental health. ${ }^{47}$ At the same time, low academic achievement levels and low income could be regarded as contributing factors arising from unfulfilled cultural, social and economic rights such as the right to education and right to employment that affect men and women unequally. ${ }^{48}$ In that sense, when economic dependency represents an obstacle for women to leave abusive relationships, this economic disparity could be traced back to unfulfilled women's rights. ${ }^{49}$ This suggests a strong connection between risk and due diligence: individuals whose rights are not adequately protected and fulfilled are at risk of further and continuous human rights violations.

Human rights and risk are different concepts, with different pedigrees, but they work well together in practice. [...] Human rights risk can be understood as harm to people, or the potential for harm to people, where that harm constitutes a violation of internationally proclaimed human rights. ${ }^{50}$

42 Heise (n 34).

43 WHO, 'Changing Cultural and Social Norms that Support Violence; Series of Briefings on Violence Prevention' (WHO 2009)

<apps.who.int/iris/bitstream/handle/10665/44147/9789241598330_eng.pdf?sequence=1\&isAllowed $=\mathrm{y}>$ accessed 10 November 2019.

44 WHO (n 30); WHO (n 35).

45 WHO (n 43).

46 United Nations Committee on the Rights of the Child, 'General Comment No 13: The Right of the Child to Freedom from All Forms of Violence' (11 April 2011) UN Doc CRC/C/GC/13; exposure to domestic violence is mentioned by the Committee on the Rights of the Child as a form of mental violence.

47 United Nations Committee on Economic, Social and Cultural Rights (CESCR), 'General Comment No 14: The Right to the Highest Attainable Standard of Health' (11 August 2000) E/C.12/2000/4.

48 CEDAW (n 7); UN International Covenant on Economic, Social and Cultural Rights (ICESCR) (adopted 16 December 1966, entered into force 3 January 1976) 999 UNTS 3.

49 CEDAW (n 7) art 10 refers to education, art 11 to employment.

50 Mark B Taylor, Luc Zandvliet and Matra Forouhar, 'Due Diligence for Human Rights: A Risk-Based Approach' (2009) John F Kennedy School of Government Corporate Social Responsibility Initiative, Working Paper $\quad$ No 53 $<$ hks.harvard.edu/sites/default/files/centers/mrcbg/programs/cri/files/workingpaper_53_taylor_etal. pdf $>$ accessed 10 November 2019. 


\section{Expanding Due Diligence: Human Rights Risk Assessments and Limits to State Interventions Aimed at Preventing Domestic Violence 189}

Consequently, taking all appropriate measures to combat IPV means addressing the root causes of these primary human rights violations, as well as secondary violations, should these arise.

It is central to this discussion to reflect on the notion of State knowledge that a human rights violation has occurred. For any form of VAW and, implicitly, IPV, State actors can only intervene when they have discovered or intercepted a disclosure of violence. At the time of disclosure, in most cases, an individual's rights have already been jeopardised. This should be considered a primary human rights violation. It then follows that due diligence requires that States prevent secondary human rights violations. However, the due diligence standard, in the context of IPV and VAW, requires States to take all appropriate measures to prevent VAW ${ }^{51}$ including combating societal risks that might lead to primary human rights violations. Therefore, taking all appropriate measures means addressing both primary and secondary human rights violations. In the context of IPV, I have named these phases anticipative prevention and escalation mitigation and they will be used to illustrate the importance of assessing risks at different levels, to achieve double protection from IPV and other forms of VAW.

\section{Due Diligence and IPV: Addressing Primary and Secondary Human Rights Risks}

Anticipative prevention requires fulfilling the human rights at the root of IPV and preventing primary human rights violations. This type of prevention should be focused on protecting economic, social and cultural rights, ensuring that harmful gender stereotypes are combated and risk factors are systematically addressed. After all, 'strategies that look at the underlying causes of violence against women ease the burden and cost of the postincidence intervention. ${ }^{52}$

In some ways, anticipative prevention is equivalent to what Rashida Manjoo, former Special Rapporteur on Violence against Women, calls systemic due diligence. ${ }^{53}$ Measures of anticipative prevention include publicising IPV, eliminating institutional victim-blaming and combating societal patterns that nurture a climate of violence by perpetuating gender stereotypes and inequalities. ${ }^{54}$

Another example of anticipative prevention is the elimination of gravity bias in State authorities and promoting legislation that sanctions new and non-physical forms of abuse, such as spiritual abuse and reproductive coercion, as well as forms of IPV perpetrated online. ${ }^{55}$ One of the most important tools of anticipative prevention is

51 CEDAW (n 7); UNCEDAW (n 3).

52 Aziz and Moussa (n 12).

53 Rashida Manjoo, 'State Responsibility to Act with Due Diligence in the Elimination of Violence Against Women' (2013) 2(2) International Human Rights Law Review 240.

54 Katherine Brickell, 'Clouding the Judgment of Domestic Violence Law: Victim Blaming by Institutional Stakeholders in Cambodia' (2017) 32(9) Journal of Interpersonal Violence 1358; Eryn O’Neal and Laura Beckman, 'Intersections of Race, Ethnicity, and Gender: Reframing Knowledge Surrounding Barriers to Social Services Among Latina Intimate Partner Violence Victims' (2017) 23(5) Violence Against Women 643.

55 NA John and J Edmeades, 'Reproductive Coercion and Contraceptive Use in Ethiopia' (2018) 32(1) Etude de la Population Africaine; HL McCauley, KL Falb, T Streich-Tilles, D Kpebo and J Gupta, 'Mental Health Impacts of Reproductive Coercion Among Women in Cote d'Ivoire' (2014) 127(1) International Journal of Gynecology \& Obstetrics 55-59; J Park, SK Nordstrom, KM Weber and T Irwin, 'Reproductive Coercion: Uncloaking an Imbalance of Social Power' (2016) 214(1) American Journal of 
education, as a mechanism to prevent inter-generational transmission of violence by addressing teen dating violence and children's exposure to parental IPV. ${ }^{56}$ The most significant feature of anticipative prevention is related to the importance of social, economic and cultural rights and how these influence IPV, as well as the fact that it reinforces the indivisibility of human rights. As risk factors are dynamic and actively interact, so must State measures aimed at protecting human rights.

However, from a human rights point of view and drawing on human rights bodies' decisions, State liability occurs at the moment State actors acquire knowledge of an abusive situation and fail to take steps to prevent the escalation of violence and further negative impacts. In that sense, escalation mitigation refers to the conduct of institutions that have, or should have, knowledge of IPV to prevent its escalation or reoccurrence. It is at this moment that State authorities have an opportunity to, and should, assess human rights risks. To avoid international responsibility, States must react to ensure that IPV is interrupted and does not continue between partners and so avoid violations of the right to life and the prohibition of ill-treatment or violations of children's rights. This requires that authorities:

(a) react pro-actively, assessing and addressing human rights risks,

(b) take measures to ensure the immediate protection of victims and

(c) ensure that protection is guaranteed without unnecessary delays and proceed to prosecute, punish and provide redress. ${ }^{57}$

In some cases, authorities must address a multitude of factors, make referrals to shelters, assist victims in getting a protection order, arrest the perpetrator and so on. This complexity makes it easy for authorities to provide uncoordinated and chaotic responses. For that reason, responses to IPV should be formalised as much as possible through protocols and statutes and laws should establish well-defined duties of State officials involved in IPV, including police forces, medical personnel, spiritual leaders, teachers or social workers. Amid growing concern that risk assessment tools used by police forces might miss certain abusive manifestations and be potentially unreliable, human rights risk assessments could facilitate new ways in which State institutions understand, discover and respond to IPV..$^{58}$

Risk assessment for violations of the right to life and prohibition of ill-treatment must include not only the victim but also their children, as they can transition from witnesses of parental violence to becoming victims themselves. As risk calculations are difficult and 'judgments must consider the who, what, where, when, and how of violence', the literature cautions against the sole use of empirical factors and suggests finding a balance between those and professional consensus. ${ }^{59} \mathrm{IPV}$ literature underlines the existence

Obstetrics and Gynecology 74-78; Zarizana Aziz, 'Due Diligence and Accountability for Online Violence against Women' (Due Diligence Project, 2017) <duediligenceproject.org> accessed 19 December 2019.

56 DS Coffey, Parenting After Violence: A Guide for Practitioners (Institute for Safe Families 2009) 1-95; CA Franklin and GA Kercher, 'The Intergenerational Transmission of Intimate Partner Violence: Differentiating Correlates in a Random Community Sample' (2012) 27(3) Journal of Family Violence 187-199.

57 Rumorv Italy App no 72964/10 (ECHR, 27 July 2014); Aziz and Moussa (n 12).

58 Jose Medina Ariza, Amanda Robinson and Andy Myhill, 'Cheaper, Faster, Better: Expectations and Achievements in Police Risk Assessment of Domestic Abuse' (2016) 10(4) Policing: A Journal of Policy and Practice 341.

59 PR Kropp, 'Intimate Partner Violence Risk Assessment and Management' (2008) 23(2) Violence and Victims 202. 


\section{Expanding Due Diligence: Human Rights Risk Assessments and Limits to State Interventions Aimed at Preventing Domestic Violence 191}

of three major risk assessment models: unstructured clinical decision making, actuarial decision making and structured professional judgment. ${ }^{60}$ The unstructured decision making model consists of risks being evaluated by professionals that come into contact with victims, relying on their experience, discretion and qualifications. This model is criticised for lacking 'reliability, validity and accountability. ${ }^{\prime 61}$ The unstructured decision model could leave excessive space for exercising stereotypical gender attitudes and should thus be complemented or replaced by additional empirical models, which may be better suited to assessing human rights impacts. States have the obligation, as per Article 5 of the UN Convention on the Elimination of Discrimination Against Women, to eliminate gender stereotypes and it is within these types of interventions that they can do so. ${ }^{62}$

The actuarial model is based on giving risk factors derived from empirical research a numerical value that generates a reflection of the possibility of re-offending. ${ }^{63}$ The effectiveness of this method appears to depend on the reliability of the data collected to determine risk factors in a specific group or location and is likely suited to assess societal factors rather than relational or individual, which vary significantly. Finally, the structured professional judgement model represents a reconciling approach between the two aforementioned methods and 'does not impose any restrictions for the inclusion, weighting, or combining of risk factors. ${ }^{64}$ When using this method, professionals assess empirical evidence and use complementary discretion to gather additional nuanced elements to determine risks. The latter model appears to be most compatible with assessing human rights risks. Furthermore, participation is a vital principle of due diligence, of great importance to guaranteeing adequate human rights protection. ${ }^{65}$ As mentioned by Taylor:

Human rights risk assessments are not mechanical processes. It is very difficult to quantify human rights risk. Checklists or compliance questionnaires, while helpful... cannot capture the quality of the risk and, therefore, the range of potential mitigations. It seems likely that the single most effective way to identify, understand and manage risks are through dialogue processes....66

For IPV, Connon-Smith et al support this idea, arguing that victims possess intuitive and sensitive information otherwise not evident in criminal records and that they ought to be involved in the risk assessment process for IPV. ${ }^{67}$

Following existing due diligence models for assessing human rights risks in business, we can extrapolate that, for IPV, human rights risks can be identified by assessing

60 ibid.

61 Kropp (n 59); Thomas Litwack, 'Actuarial Versus Clinical Assessments of Dangerousness' (2001) 7 Psychology, Public Policy and Law 409.

62 UN General Assembly, 'Declaration on the Elimination of Violence against Women' (20 December 1993) UN Doc A/RES/48/104.

63 State of Victoria, 'Royal Commission into Family Violence: Report and Recommendations' (2014-2016) Vol I, Parliamentary Paper No 132.

64 Kropp (n 59).

65 Danish Institute for Human Rights, 'Human rights Impact Assessment: Guidance and Toolbox' (Danish Institute for Human Rights, 2016) $<$ humanrights.dk/sites/humanrights.dk/files/media/dokumenter/business/hria_toolbox/introduction /welcome_and_introduction_final_may2016.pdf_223791_1_1.pdf> accessed 19 December 2019.

66 Taylor (n 50).

67 Jennifer Connor-Smith et al, 'Risk Assessments by Female Victims of Intimate Partner Violence: Predictors of Risk Perceptions and Comparison to an Actuarial Measure' (2011) 26(12) Journal of Interpersonal Violence 2517. 
a) the right holders;

b) the human rights context and

c) the potential for State involvement. ${ }^{68}$

Assessing the right holders should involve a key examination of the individual risk factors of the victim and children, as well as a thorough analysis of recidivism and risks of perpetration. Here, State actors must uncover whether the circumstances leading to violence originate from other human rights violations, if individuals are aware of their human rights and if violations to children's rights have occurred, as well as determining other potential right holders and assessing other harms and damage, for example to property or pets.

The human rights context should be analysed in an attempt to understand the degree of vulnerability of the victim, their socio-cultural makeup and the obstacles they face which make them susceptible to primary human rights violations. Here, it is important that State actors expose socioeconomic motivations for accepting or justifying the abuse and that they work with victims in finding viable and sustainable solutions to address those factors. Finally, and perhaps most importantly, acting diligently requires States to evaluate the available space for intervention and analyse what logistical, material and institutional support they can provide victims to ensure safety, access to justice, remedies and redress. ${ }^{69}$ All these phases must be guided by the principles of participation: non-discrimination, empowerment, transparency, accountability and ensuring that the victim and children are involved..$^{70}$

\section{Limits to State Due Diligence for the Prevention of IPV}

Any State intervention must thus be aimed at mitigating the intensification of violence and preventing primary and secondary human rights violations. However, States also have negative human rights obligations; that is, they must not interfere in the enjoyment of a particular right unless such interference is exceptional and such exception is rendered permissible by international law. ${ }^{71}$ What is then the difference between a State intervention and State interference in the context of IPV and other forms of violence against women?

This analysis must be carried out within the precincts of the norms and jurisprudence developed by the European Court of Human Rights that have repeatedly examined the boundaries of the right to private life. State interference appears in Article 8 of the European Convention on Human Rights (ECHR):

There shall be no interference by a public authority with the exercise of this right except such as is in accordance with the law and is necessary in a democratic society in the interests of national security, public safety or the economic well-being of the country, for the prevention of disorder or crime, for the protection of health or morals, or for the protection of the rights and freedoms of others. $^{72}$

The ECHR thus allows State interferences prescribed by the law and necessary for public safety. If State measures aim to prevent crime, are prescribed by national law and are necessary, in the sense that they are proportional and respond to a pressing social need,

68 Taylor (n 50); Danish Institute for Human Rights (n 65).

69 Taylor (n 50).

70 Danish Institute for Human Rights (n 65).

71 Ida Elizabeth Koch, 'Dichotomies, Trichotomies or Waves of Duties?' (2005) 5(1) Human Rights Law Review 81-83.

$72 \operatorname{ECHR}(\mathrm{n} 11)$ art 8. 


\section{Expanding Due Diligence: Human Rights Risk Assessments and Limits to State Interventions Aimed at Preventing Domestic Violence 193}

they can be considered legitimate interferences. Addressing IPV is increasingly becoming a pressing social need, as demonstrated by the unshaking prevalence of IPV against women worldwide. However, it is clear that balancing the rights of individuals, their autonomy and freedom, with the need to combat IPV could, in some cases, become problematic from a human rights perspective.

The ECtHR has put forward that the positive obligation of States is binary: '...to give legal recognition to family ties; the second is to act to preserve family life. ${ }^{73}$ An important question resurfaces: aside from preventing IPV, should State interventions in IPV be aimed at preserving or terminating a violent relationship? Is the aim of preserving a relationship compatible with the prevention of future violence in IPV cases? Which State conduct, in terminating or preserving a relationship, is most compatible with human rights standards?

Regarding the preservation of family life, the ECtHR has not discussed this aspect in the context of IPV; instead, this issue was examined in cases concerning children's separation from their parents. ${ }^{74}$ The inquiry on the role of the State in preserving family life is not novel in the sphere of sociology, although vastly ignored in the field of human rights. Zimmerman highlighted the relationship between social welfare support and the preservation of family in the United States and noted that 'family and social integration are two sides of the same coin, that family life is more stable in States that do more to support individuals and families in the face of destabilizing influences. ${ }^{75}$ Family preservation was also introduced in the context of children's welfare programmes and the model was regarded positively. ${ }^{76}$

Since then, others have agreed that the State must "provide a certain level of material conditions in order to preserve family life. ${ }^{77}$ Most of the ideas in family preservation are centred around the role of the State in providing socio-economic support for families and exercising paternalism to protect children while strengthening the capabilities of parents to provide safe spaces for children. On one hand, State measures aimed at fulfilling economic, social and cultural rights could lower individual and relational risk factors associated with IPV and decrease marital conflicts and economic stress and dependency within couples. But family preservation in the sense of relationship preservation in IPV does not appear to have been largely discussed. One author signals the issue women face:

Remedies for domestic violence too often protect a woman's right to safety only if she is willing to leave her partner, thereby sacrificing her right of autonomy as expressed through her decision to stay in an intimate relationship. [...] The legal system must confront the tension between legal rules that assume that the only solution to domestic violence is to dissolve the relationship. ${ }^{78}$

73 European Court of Human Rights, 'Guide on Article 8 of the European Convention on Human Rights, Right to Respect for Private and Family Life' (Council of Europe, 31 August 2019) <echr.coe.int/Documents/Guide_Art_8_ENG.pdf> accessed 19 December 2019.

74 ibid.

75 Shirley Zimmerman, 'The Role of the State in Family Life: States' AFDC Payments and Divorce Rates in the United States' (1994) 14(1) International Journal of Sociology and Social Policy 4.

76 S Kelly and BJ Blythe, 'Family Preservation: A Potential Not Yet Realized' (2000) 79(1) Child Welfare 29.

77 Maribel Gonzalez Pascual and Aida Torres Pérez (eds), The Right to Family Life in the European Union (Taylor \& Francis 2016) 7.

78 Sally Goldfarb, 'Reconceiving Civil Protection Orders for Domestic Violence: Can Law Help End the Abuse Without Ending the Relationship' (2007) 29 Cardozo Law Review 1487. 
Therefore, perhaps the biggest challenge of due diligence compliance in IPV is reconciling two competing State interests:

(a) the interest of the State in respecting an individual's right to autonomy and selfdetermination in their private life and

(b) the interest of the State to protect an individual from the possible consequences of exercising that autonomy and consequently act in the name of public safety.

This conundrum is also reflected in the public-private divide that has characterised IPV for a long time, namely the reluctance of public authorities to intrude in what has been considered a private, family issue. However, due diligence obligations have put an end to this traditional divide, as recent developments, along with the work presented here, clearly suggest that IPV is a public issue. Nonetheless, the publicity of IPV does not exclude the possibility of some elements, related to romantic relationships, retaining a private character.

Goldfarb suggests that the law should provide for the possibility of various forms of protection orders: 'a protection order that authorizes an ongoing relationship between the parties but sets limits on the abuser's behaviour provides a valuable alternative. ${ }^{79}$ Indeed, State measures imposing flexible limitations would utilise the power of the law for 'improving relationships rather than ending them', empowering victims which might, in some cases, reflect higher compliance with human rights standards. ${ }^{80}$

\section{Conclusion}

This article has illustrated that IPV is a complex issue that involves primary and secondary human rights violations. The article has argued that to comply with due diligence obligations to prevent IPV, States must assess human rights risks and must design State interventions aimed at addressing individual, relational and societal risks associated with IPV. State interventions are not absolute, and they must consider an individual's agency, needs and desires. Central to effective State conduct is the participation of the victim of IPV in the risk assessment process. More research is needed, not only for IPV but for all forms of VAW, to exemplify how human rights violations arise from gender-based violence and to develop a human rights risks assessment framework to aid States in compliance with their obligations and, at the same time, protect victims of IPV. Human rights risk assessment tools, combined with human rights education for State actors involved in IPV, have the potential of uncovering intersectional vulnerabilities and addressing the root causes of gender-based violence, whilst concomitantly ensuring compliance with the right to private and family life. The relationship between risk, violence and human rights compliance exemplified here can analogously be applied to child abuse, elder abuse and other forms of inter-personal violence that require complex State interventions, often involving balancing the human rights of multiple individuals. 